\title{
Romantic Dharma:The Emergence of Buddhism into Nineteenth-Century Europe, by Mark S. Lussier
}

Nineteenth-Century Major Lives and Letters | New York: Palgrave Macmillan, 20I $\mid \mathrm{xx}+23 \mathrm{I}$ pages | ISBN: 978-0-230I $0545-4$ (hardback) $\$ 90.00$

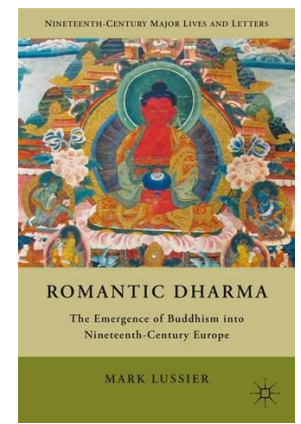

The emergence of a distinctly western form of Buddhism has become somewhat of an academic cottage industry in recent decades, and tracing the origins of this new form of spirituality to the late eighteenth and early nineteenth centuries is a distinct sub-specialty. To this field comes Professor Lussier to add a new element for our consideration: What relation, if any, is there between the growing awareness of Buddhism in nineteenth-century Europe and the rise of Romanticism?

By its very nature, this must be a speculative work. Lussier does not fall into the trap of imputing to Romantic writers more knowledge of Buddhism than they are known to have possessed. He does not turn Shelley into an anonymous Shantideva, nor Blake into a British Bodhidharma. What he does illustrate is far more subtle.

For Lussier, Buddhism represents a challenge to the classical Saidian view of Orientalist hegemony. Buddhism was not merely a pawn in the Great Game of western colonial conquest: it "capably exerted a broad counterinfluence in Europe across the nineteenth century," and "unlike almost all other Eastern religions and systems of thought, Buddhism has cast long shadows across the West, even ... establishing a significant presence within it" (23).

What Lussier proceeds to do with the rest of his book is not merely to describe this process, but to demonstrate it. His exposition does not follow western, Aristotelian forms of argumentation. It is built on the fluid, conditionalist thinking of Buddhist philosophy. Buddhism could have entered the western cultural consciousness at any time. As I have argued elsewhere, the geographical and cultural boundaries separating Europe and Asia were not insurmountable, not when a Buddha-rupa has been found in a Viking treasure hoard in Sweden, not when the Buddha, under the name Chagamoni Burkhan, was known from the writings of Marco Polo, not to mention venerated as a saint under the name Josaphat.

Buddhism entered the Euro-American sphere when it did because the conditions came into being that allowed it to do so. And what do we find in 
Europe at precisely the same time? Romanticism. This does not imply that Romanticism "paved the way" for Buddhism (or, even less, vice versa). What Lussier shows in this book is that both Romanticism, the home-grown product, and Buddhism, the exotic import, reflected and brought about a fundamental change in the Zeitgeist. It is a perfect example of pratityasamutpada, conditionality rather than causality.

Much can still be said on this topic. Both Romanticism and Buddhism have their Jungian shadows, their dark sides, and these would become all too clear in the twentieth century, unfortunately not part of the scope of this particular volume or the series in which it appears. For now, it is not the content of this book that delights (although it needs to be said that the chapter on Csoma de Korös contains material that has been obscured for far too long), but the approach, the methodology. Buddhology has long endured debates over the status of the Buddhist scholar/practitioner. Here, in a different academic context, we can see the results of a Buddhist view of reality allied to thorough western scholarship. Read this book. It may just reflect the future direction of the humanities. 